方法は，前述の公園の芝生広場に定点観測用カメラを設置 し， 5 月 1 日から毎日， 10 時， 12 時， 14 時， 16 時に写真 を撮影し，利用状況を記録した。解析では，写真に写りこん だ利用者数を計測するとともに，1日の積算利用者数が最大 となった日について, グループ間の距離を計測した。

その結果，都市型の舞子公園でみると，最多利用日の 5 月 24 日(日) 16 時では, 25 人 (10 グループ) の利用があっ たが，グループ間の距離は全て $2 \mathrm{~m}$ 以上となっており，一 定の距離が保たれていた（写真-2）。郊外型の淡路島公園で は，4 時間の利用を積算した利用者数でみると，緊急事態宣 言が解除された日以降の土日の利用が増加し，5月 24 日 (日)には 130 人以上 $(16$ グループ) と最大となった (図 -1$)$ 。 これら利用が最大となった日においても最も近いグループ間
距離は $2 \mathrm{~m}$ 以上と一定の距離が保たれていた5)。

\section{3) まとめ}

都市公園の利用は緊急事態宣言の解除に伴い増加傾向であ るが，その状況は公園の立地により異なっていた。すなわ ち，利用者の移動手段や公園の立地等による緑の利用の検討 が重要と思われる。

\section{引用文献}

5) 山本 聡, 訔山洋志, 薬師寺恒治, 守 宏美, 中瀬 勲 （2020）コロナ禍での大規模都市公園の芝生広場利用, 2020 年度日本造園学会関西支部大阪大会要旨集.

\title{
【報告 4】
}

\section{コロナ禍での京都・賀茂川河川敷の緑地利用の状況}

\section{福井 亘 京都府立大学大学院}

\section{1）非日常}

新型コロナウイルス感染症により，京都市内でも最初の陽 性者が確認された後, 全国と同様の措置が進められ, 生活や 時間の制限が示されてきた。これは，人の生活そのものを大 きく見直さざるを得ず，仕事と生活の場を居住空間へ「留め る」すなわち「籠る」ことへ多くの国民が社会的要請として 対応した。そういった状況下においての人の精神や心身の健 全化を考えると「緑」はどう役割を担うのか考える必要があ ると思われた。本稿は, 京都の賀茂川(鴨川)の河川敷を日々, 観察してきたことについて，事例報告をするものである。

当初，陽性者が出た際，市内には差し迫った緊迫感はみら れず，危機意識が市内においては希薄であった。当時，市内 では，ほぼ変わらない生活があり，公園利用は普段通りの様

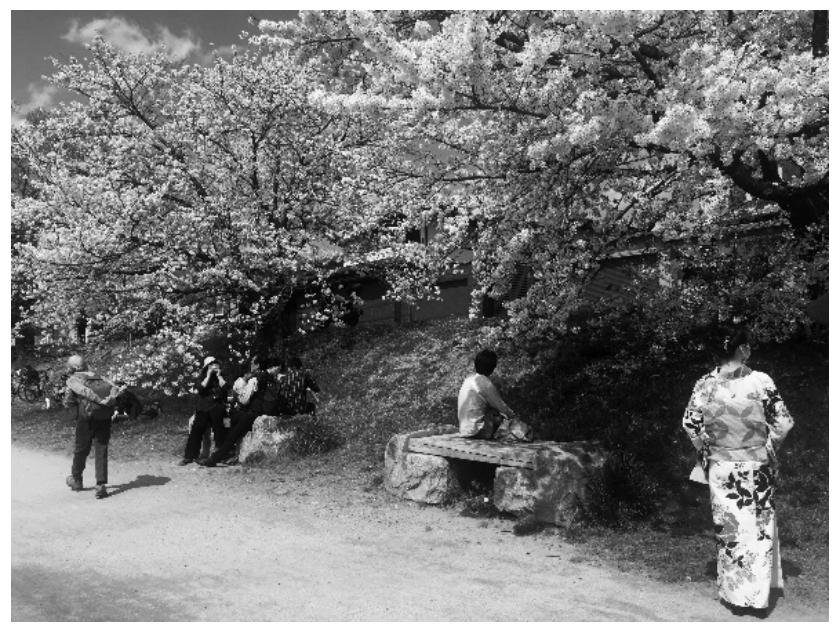

写真-3 春の花見の光景
相を呈していた。その後，全国的な感染流行に伴い，外出の 減少，各施設の閉鎖といった状況に変化した。その状況から は，街区公園に加え，賀茂川の河川敷でも，ほぼ利用する市 民が見られなかった。恐らくこれは，行政による外出自肃， 注意喚起によるところが多い結果である。

これから非日常の生活が始まり, 我々にとっての大きな生 活の転換点と言えるが，外部に出ること自体，ままならない 状況だとすれば，公園などの緑地空間が利用されないのは必 然と言える。それまでは，子供たちが遊び，多くの方が談笑 するといった場であり，飛沫，接触感染は最も考えるべき点 からも利用不可の措置は，利用者激減として大きい結果と言 える。

\section{2）四季の文化}

3 月下旬から 4 月上旬には, 開花したサクラが見られる。 それまで外出を控えていた市民が，感染症に気を付けながら も例年の四季の文化でもある「花をみる」ことに楽しみだし ていた（写真-3）。賀茂川河川敷では，例年通りに花見の出 来る所での人が多く行きかい，小さな花見宴会も遠慮がちに されている光景を見るに，京都の市民，府民にとっての大き な四季行事でもあることと，部屋に籠っていることから，抜 け出して，外へ外へと花を見に出て来たものと言える。部屋 の中でも観葉植物や家の庭，ベランダなどにより緑を目にす ることはあったとしても，やはり外の空間での緑や花の存在 には，気持ちとしても良いものではないかと思われた。海外 や他府県からの入洛は自肃されている中, 人出は例年より少 ないと思っていたが，逆に例年よりも人通りは多い感じを受 けた。恐らく,「内から外へ」といった意識によることかと思 われる。 


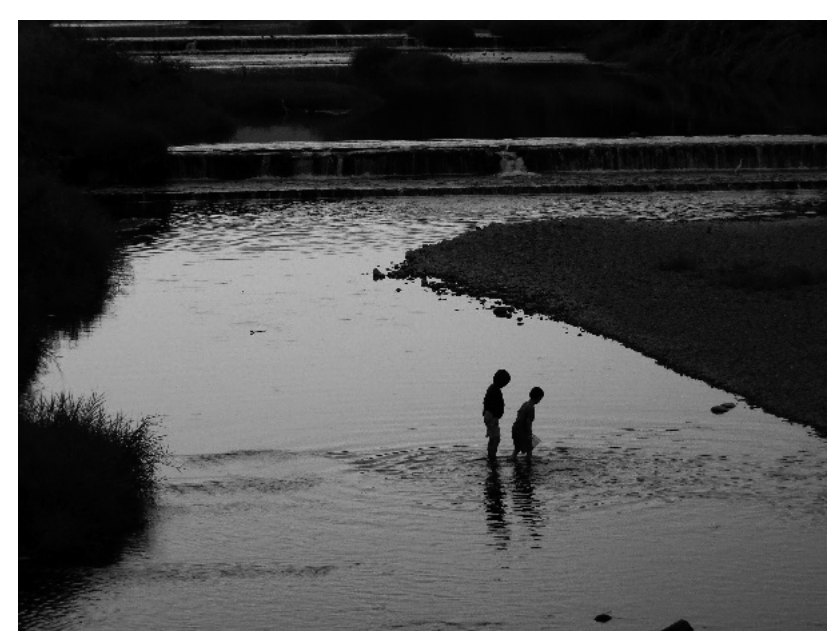

写真-4 夏夕の水遊び

その後の 5 月頃には, 散歩などで利用する人が例年より 多く感じ, 全国的に生活制限はされていたものの, 連休や休 日が人の行動を動き易くしているのではと思われる。6月か ら徐々に気温が上昇すると共に, 人通りは例年通り増え, 特 に 7 月から 9 月にかけては, 休日だけではなく平日にも利 用する人が増加していた。夏季になると河川敷での水遊びが 多く, 家族で訪れる光景も多くみられた (写真 -4$)$ 。

また, 中高生や大学生の運動・文化活動での利用もこの時

\section{【報告 5】}

\section{東海地方における公園利用}

\section{加藤祥子岐阜市立女子短期大学}

2020 年 4 月 7 日に 7 都府県を対象に緊急事態宣言が出さ れた際に, 東海 3 県（愛知県・岐阜県・三重県）はその対 象には含まれていなかった。愛知県・岐阜県・三重県は, 平 素から人・物の交流が盛んであり，連携して対応する方針が 示された (4月 7 日「緊急事態宣言」発令に際しての愛知・ 岐阜・三重 3 県知事緊急共同アピール)。4 月 10 日には, 愛 知県が県独自の「愛知県緊急事態宣言」, 岐阜県が「非常事 態宣言」を発するなど, 東海地方の感染状況は警戒が必要な 状態であった。

緊急事態宣言のもと, 外出の自肃が求められた一方, 医療 機関への通院, 食料・医薬品・生活必需品の買い出し, 職場 への出勤, 屋外での運動や散歩など, 生活の維持に必要なこ とについては, 外出の自肃要請の対象外とされた。学校の休 校やレジャー施設の休園などにより, 多くの人が, 身近な公 園を訪れ, 運動や息抜きをしてリフレッシュし, 公園の価值 を再認識した。その中で, 県や市区町村が管理する都市公園 については，閉鎖や一部閉鎖など，様々な対応が取られた。 公園以外の施設の閉鎖に伴い, 公園に人が押し寄せることが 懸念された地域では, 都市公園すべての閉鎖が実施された事
期より多く確認でき, ウォーキングやジョギングといった学 生だけではなく一般の人の健康増進に関わる活動自体も目 立ってきた。その傾向は, 初夏から夏, 秋に至るまで確認で きている。健康や身体活動の緑地への利用と活用 ${ }^{6}$ について 賀茂川の河川敷が役立っていた可能性がある。

賀茂川自体，京都市内の中を流れ，市民との距離が近い。 それは, 京都市民, 府民にとって, 来訪しやすい環境でもあ り, 比較的利用しやすく, かつ四季を感じられるといったこ と7からも, 賀茂川への来訪を促進してきたのではと思われ た。これは, 賀茂川の存在が日常の存在空間であり, それは 生活景として存在しているに他ならない。こういったことか ら, 賀茂川河川敷の緑地利用は, 他都市と少しばかり異なっ た空間認識に当たるかもしれない。なお, 本稿では, 統計的 に調査をしていないことから, 科学的なデー夕提示ではな く, 著者による観察からの主観であることをご了解いただき たい。

\section{引用文献}

6) Wang, H., Dai, X., Wu, J., Wu, X., and Nie, X. (2019) Influence of urban green open space on residents' physical activity in China. BMC Public Health, 19: 1-12.

7）福井 亘 - 佐竹悠理 - 濱田 梓・正嶋大作・瀨古祥子 - 高 林 裕（2017）京都鴨川の景観と春から秋の季節変化の魅 カについて. ランドスケープ研究, 80(5): 609-614.

例も見られた。一方, 体育館や庭球場, 野球場などの一部施 設のみ閉鎖とし，芝生広場などは注意喚起を揭示した上で開 放している事例も見られた。「1)マスクを着用し，距離を保 つこと (2)密集, 密接となる行為をしないこと (3)遊具使用後 は, 手洗いを徹底すること」などが公園の入口等に掲示さ れた。

緊急事態宣言が解除されたあとも，公園はリフレッシュの 空間として地域住民に活用されている様子が伺われた。季節 が夏に近づくにつれ, 熱中症への懸念も梁まり, 屋外でのマ スクの着用などに注意が必要となった。また, 夏休み期間に おいても, 愛知県では, 人の移動が盛んになるお盆の期間を 念頭に, 二度目の「愛知県緊急事態宣言」, 岐阜県でも「第 2 波非常事態」に対する緊急対策が出され，県をまたぐ不要 不急の外出の自肃が要請された。海水浴場などが閉鎖され, 身近な河川が水遊びの場となり, 河川における水難事故が増 加しているとの報道も見られた。

身近な公園の利用者として, 特に未就学児の保護者として は, 身近な公園は平時にも増して, なくてはならない空間で あったと感じている。年少者のみならず，多くの人々が外出 